\title{
Momordica cochinchinensis (L.) Spreng. Aril Extract Prevents Adverse Reproductive Parameters of Male Rats Induced with Valproic Acid
}

\author{
El Extracto del Arilo Momordica cochinchinensis (L.) Spreng. Previene los Parámetros \\ Reproductivos Adversos Inducidos con Ácido Valproico en Ratas Macho
}

Wannisa Sukhorum ${ }^{*, * *}$; Apichakarn Sampannang ${ }^{*, * *}$; Bungorn Sripanidkulchai* ${ }^{* *}$ \& Sitthichai Iamsaard ${ }^{*, * *,+}$;

SUKHORUM, W.; SAMPANNANG, A. \& SRIPANIDKULCHAI, B. \& IAMSAARD, S. Momordica cochinchinensis (L.) Spreng aril extract prevents adverse reproductive parameters of male rats induced with valproic acid. Int. J. Morphol., 34(3):870-876, 2016.

SUMMARY: This study aimed to investigate protective effect of Momordica cochinchinensis (MC) aril extract on adverse reproductive parameters of male rat induced with valproic acid (VPA) commonly used in treatment for antiepileptic diseases. Male Wistar rats were divided into 6 groups (control, VPA, $200 \mathrm{mg} / \mathrm{kg} \mathrm{BW}$ of PE only, and 50, 100, $200 \mathrm{mg} / \mathrm{kg} \mathrm{BW} \mathrm{MC+VPA,} \mathrm{respectively).}$ Animals were pretreated with aqueous MC extract for 23 days before co-administered with VPA induction for 10 days. At the end of experiment, all male reproductive parameters and testicular histology were examined. The results showed all doses of PE significantly protect the decrease the weights of epididymis and seminal vesicle but not of body and testicular weights. MC extract also increased sperm concentration and seminiferous tubular diameters in MC+VPA co-administrative groups. Moreover, testicular histology of MC+VPA groups showed significant declining of testicular histopathologies as compared to VPA group. It was concluded that $M$. Cochinchinensis aril extract can prevent adverse male reproductive parameters and testicular damage induced with VPA.

KEY WORDS: Momordica cochinchinensis; Valproic acid; Male reproductive parameters; Testicular damage; Rats.

\section{INTRODUCTION}

Momordica cochinchinensis (MC) Lour. Sprengel or Fag Kaow is a kind of melon; its fruit (also called Gac fruit) has been used as a traditional medicinal plant and alternative food in many countries especially in Asia, including Thailand. Recently, various scientific studies have shown that MC fruit extract has antioxidant and pharmacological properties (Kubola \& Siriamornpun, 2011). MC has been demonstrated to have anti-cancer activities (Zheng et al., 2014; Jung et al., 2013a; Liu et al., 2012; Chuethong et al., 2007; Tien et al., 2005). In addition, it was also reported for its anti-inflammatory effect (Jung et al., 2013b) and angiogenesis (Kang et al., 2010). Moreover, MC extracts have been shown to have immunomodulatory activity (Tsoi et al., 2006) against H5N1 avian influenza (Rajput et al., 2007), foot and mouth disease (Xiao et al., 2007), Newcastle disease (Xiao et al., 2009), and infectious bursal disease (Rajput et al., 2010), respectively.
Valproic acid (VPA) is a common antiepileptic drug recently used in the administrations of brain disorders including epileptic seizures, panic attack, posttraumatic stress disorder, bipolar disorders, migraine, anorexia nervosa, anxiety disorder, and psychiatric conditions (Loscher, 2002). Although, VPA has various therapeutic properties (Gelder et al., 2006), many side effects have also been documented such as congenital malformations (Jentink et al., 2010; Witczak et al., 2010) and increased fibrosarcomas and adenocarcinomas of the uterus and cervix (Watkins et al., 1992). Particularly, VPA causes adverse effects of male reproductive parameter in human and animals. Previous studies have shown that the testosterone levels and semen qualities of epileptic men being treated with VPA significantly decreased (Herzog, 2008; Bauer et al., 2004; Isojärvi et al., 2004; Roste et al.

\footnotetext{
* Department of Anatomy, Faculty of Medicine, Khon Kaen University, Khon Kaen, Thailand.

** Center for Research and Development of Herbal Health Product, Faculty of Pharmaceutical Sciences, Khon Kaen, Thailand. Grants: This project was financially supported by Invitation research grants, Faculty of Medicine, Khon Kaen University (No.I-57234) and Center for Research and Development of Herbal Health Product, Faculty of Pharmaceutical Sciences (No. RD-HHP 05).
} 
2003). Bauer et al. have suggested that such adverse effects involved male infertility. In experimental animals, VPA not only significantly decreases $\mathrm{FSH}, \mathrm{LH}$, and testosterone levels but also damages testicular tissue (Khan et al., 2011; Bairy et al., 2010; Krogenase et al., 2008; Hamza \& Amin, 2007; Svenberg Roste et al., 2002; Nishimura et al., 2000). Currently, many medicinal plants have been used in searching for alternative treatments to prevent such side effects of VPA administration (Sakr et al., 2014; Hamza \& Amin). Although, Momordica cochinchinesis (MC) has been demonstrated to have antioxidant activities and various phyto-therapeutic properties, the preventive effects on adverse male reproductive parameters and testicular damage have never been reported. Therefore, this study aimed to demonstrate the protective effect of MC aril extract on male reproductive organs damaged in VPAinduced.

\section{MATERIAL AND METHOD}

Plant collection and extraction: The trees of Momordica cochinchinensis (Lour.) Spreng were planted at a farm in Kuchinarai district, Kalasin province, Thailand. All parts of M. cochinchinesis (MC) were identified for its actual species by Prof. Dr. Pranom Chantaranothai, a professional plant taxonomist, Department of Biology, Khon Kaen University. Thailand. The vouchers of dried plant samples were kept in the KKU plant herbarium (No. Apichakarn Sampannang 01 [KKU]). MC-ripe fruits were cultivated on May, 2014. Each fruit was cut through at middle line to collect arils (red color) covering seeds. The aril parts were separated from the seeds by gentle squeezing. After that, MC aril were mixed with distilled water (1:1 ratio), blended by stainless electric spinner (trademark, Tafal, BL116), and finally filtered by nylon cloth (2 layers) for 2 times. Then, MC juice was dried to produce powder extract by Spray dryer (Nitro A/S-Gladsaxevej 350-DK-
2860 Soeborg, Denmark) at the Faculty of Phamacentical Sciences, Khon Kaen University, Thailand. The percentage yield and antioxidant activities were determined and approved by Assist. Prof. Somsak Nualkaew, Department of Pharmaceutical Sciences, Faculty of Pharmacy, Mahasarakham University, Mahasarakham, Thailand.

Animals and treatment regime: Male Wistar rats (180$200 \mathrm{~g}$ ) were purchased from the National Laboratory Animal Center, Salaya, Nakhon Pathom, Thailand. They were acclimatized for 7 days before using in experiment at Northeast laboratory animal center (NELAC), Khon Kaen University, Thailand. Animals were maintained with commercially standard pellet diet and tap water ad libitum and housed in polycarbonate cages containing wood chip bedding under the controlled condition of a $12 \mathrm{~h}$ light/ dark cycle. After acclimatization, 48 male rats were divided into six groups ( $n=8$ in each group) and were treated as shown in Table I. The study was approved by the Animal Ethics Committee of NELAC, KKU, based on the Ethics of Animal Experimentation of the National Research Council of Thailand (ref. No. 0514.1.12.2/12 with record No. AEKKU-NELAC 17/2557).

Sperm concentration analysis: The cauda epididymal sperm concentration was performed as previously described in Iamsaard et al. (2014). After animal euthanasia, the sperm fluid was squeezed from both left cauda epididymis and vas deferens. Milky-like sperm fluid was dipped and re-suspended in $1 \mathrm{~mL}$ of phosphate buffer saline $\left(37^{\circ} \mathrm{C}, \mathrm{pH} 7.4\right)$. Then, sperm suspension was centrifuged ( $3000 \mathrm{rpm}, 37^{\circ} \mathrm{C}, 2 \mathrm{~min}$ ) to wash and separate the mature sperm pellet from epididymal fluid. To examine the cauda epididymal sperm concentration, such sperm pellets were re-suspended again with $1 \mathrm{~mL}$ fresh PBS (37 ${ }^{\circ} \mathrm{C}, \mathrm{pH}$ 7.4) before dilution. The diluted sperm (1:20-50 dilution) were counted for three times of each animal by using a Neubauer's counting chamber and calculated for its concentration (represented as 106 sperm cell $/ \mathrm{mL}$ ).

Table I. Treatments of control and experimental groups

\begin{tabular}{lcc}
\hline \multirow{2}{*}{ Groups } & \multicolumn{2}{c}{ Treatments } \\
\cline { 2 - 3 } & Days 1-23 (via a gastric tube) & Days 24-33 (intraperit oneal injection) \\
\hline Control & Distilled wa ter, $1 \mathrm{~mL}$ & Saline, $0.5 \mathrm{~mL}$ \\
VPA & Distilled wa ter, $1 \mathrm{~mL}$ & VPA $(500 \mathrm{mg} / \mathrm{kg} \mathrm{BW}), 0.5 \mathrm{~mL}$ \\
MC200 & $\mathrm{MC}$ aril extracts $(200 \mathrm{mg} / \mathrm{kg} \mathrm{BW}), 1 \mathrm{~mL}$ & $\mathrm{Saline}, 0.5 \mathrm{~mL}$ \\
MC50+VPA & $\mathrm{MC}$ aril extracts $(50 \mathrm{mg} / \mathrm{kg} \mathrm{BW}), 1 \mathrm{~mL}$ & $\mathrm{VPA}(500 \mathrm{mg} / \mathrm{kg} \mathrm{BW}), 0.5 \mathrm{~mL}$ \\
MC100+VPA & $\mathrm{MC}$ aril extracts $(100 \mathrm{mg} / \mathrm{kg} \mathrm{BW}), 1 \mathrm{~mL}$ & $\mathrm{VPA}(500 \mathrm{mg} / \mathrm{kg} \mathrm{BW}), 0.5 \mathrm{~mL}$ \\
MC200+VPA & $\mathrm{MC}$ aril extracts $(200 \mathrm{mg} / \mathrm{kg} \mathrm{BW}), 1 \mathrm{~mL}$ & $\mathrm{VPA}(500 \mathrm{mg} / \mathrm{kg} \mathrm{BW}), 0.5 \mathrm{~mL}$ \\
\hline
\end{tabular}

$\mathrm{BW}=$ body weight; VPA= valproic acid (saline-dissolved). The VPA group (Negative control) is designed based on Hamza \& Amin (2007) $(\mathrm{n}=8)$.

The preventive period (Days 1-23) and VPA-induction period (Days 24-33). 
Histopathological examinations of the testes: At the end of the treatment period, all rats of control, MC, VPA and MC-VPA coadministrative groups were first weighed and euthanized by cervical dislocation to carefully collect testis and epididymis plus vas deferens. Immediately, the testis were cleaned of fats and weighed. Then, right testes were fixed in $10 \%(\mathrm{v} / \mathrm{v})$ formalin in phosphate buffered saline (PBS) ( $\mathrm{pH} 7.4$ ), dehydrated, embedded in paraffin, sectioned at 5-7 mm thickness, and stained with routine hematoxylin-eosin to make the permanent glass slides (Iamsaard et al.). All sections of testes were examined for histopathology under a Nikon light ECLIPSE E200 microscope equipped with a DXM1200 digital camera, Department of Anatomy, Faculty of Medicine, Khon Kaen Universty, Thailand. Approximate average diameters of seminiferous tubules in four different axes (50 tubules per animal) (10x) were measured and calculated by using ImageJ program (Iamsaard et al.).

Statistical analysis: To determine the significance of differences among experimental groups, the one-way analysis of variance (ANOVA) and ttest were applied by using Sigma Stat program (Version 3.1.1). All quantitative data were expressed as Mean \pm Standard Deviation (SD).

\section{RESULTS}

The results showed that the body weight of VPA- and MC-VPA treated rats were significantly decreased although that of MC200+VPA group tended to be improved (Table II). In addition, both absolute and relative weights of the testes in all experimental groups were corroborated with those body weights (Table II). In contrast, these results demonstrated that VPA could significantly increase the absolute except relative weight of epididymis plus vas deferens as compared to the control. In coadministrative groups (Table II), this result showed that the low and high doses of MC extract significantly increased the absolute weight of epididymis plus vas deferens in rats induced with VPA, compared to the VPA group. However, all MC extract (50, 100, and $200 \mathrm{mg} / \mathrm{kg} \mathrm{BW}$ ) significantly improved the relative weights of weight of epididymis plus vas deferens in VPA rats $(\mathrm{P}<0.05$; Table II). Interestingly, MC extracts could significantly ameliorate both absolute and relative weight of seminal vesicles compared with only VPA-induced group $(\mathrm{P}<0.05$; Table II). Moreover, this study showed that MC extract in all doses could significantly prevent the reduction of sperm concentration in male rats induced with VPA induced ( $<<0.05$; Table II). Although MC extract tended to prevent the decrease of seminiferous tubule diameters in testis of VPA rats, there was no significant difference (Table II).

In histopathological examination of the testis, the results showed that MC extract ( $200 \mathrm{mg} / \mathrm{kg} \mathrm{BW}$ ) did not affect testicular tissues compared with the control demonstrating normal arrangement of seminiferous epithelium and interstitial tissues (Figs. 1 A and B). In contrast, the testicular damages presenting various seminiferous tubule degeneration and atrophy, multinucleated giant cells, dilated blood vessels, and spacious interstitial tissue were observed in the testis of rats induced

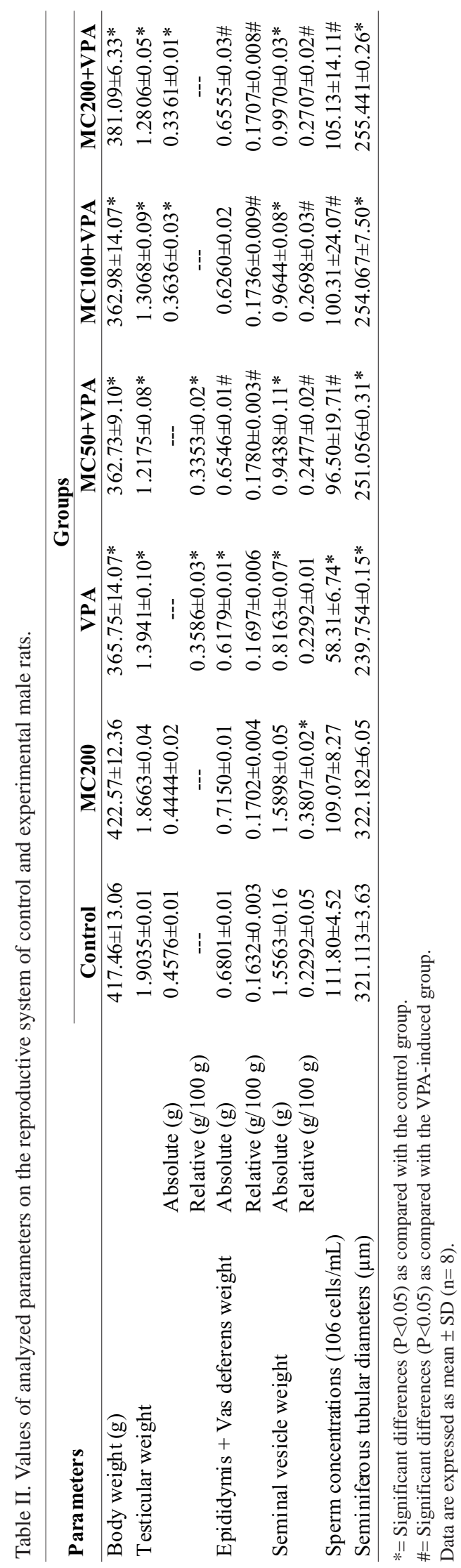


with VPA (Fig. 1C). It seems that these testicular damages were dose-dependent, improved by MC preventing treatments (Figs. D, E and F). In MC 50+VPA group, there was the decrease of seminiferous tubule atrophy and epithelial degeneration but did not improve the degenerative interstitial tissues as compared with the control (Fig. 1D). In MC100+VPA group, no atrophy and slight degeneration were found whereas some nucleated giant cells in seminiferous tubule and broad interstitial spaces were still present (Fig. 1E). In MC 100+VPA group, the results showed the improved histology of testis tissue as compared to the control and VPA groups although some nucleated giant cells were still found, located within seminiferous epithelium (Fig. 1F).

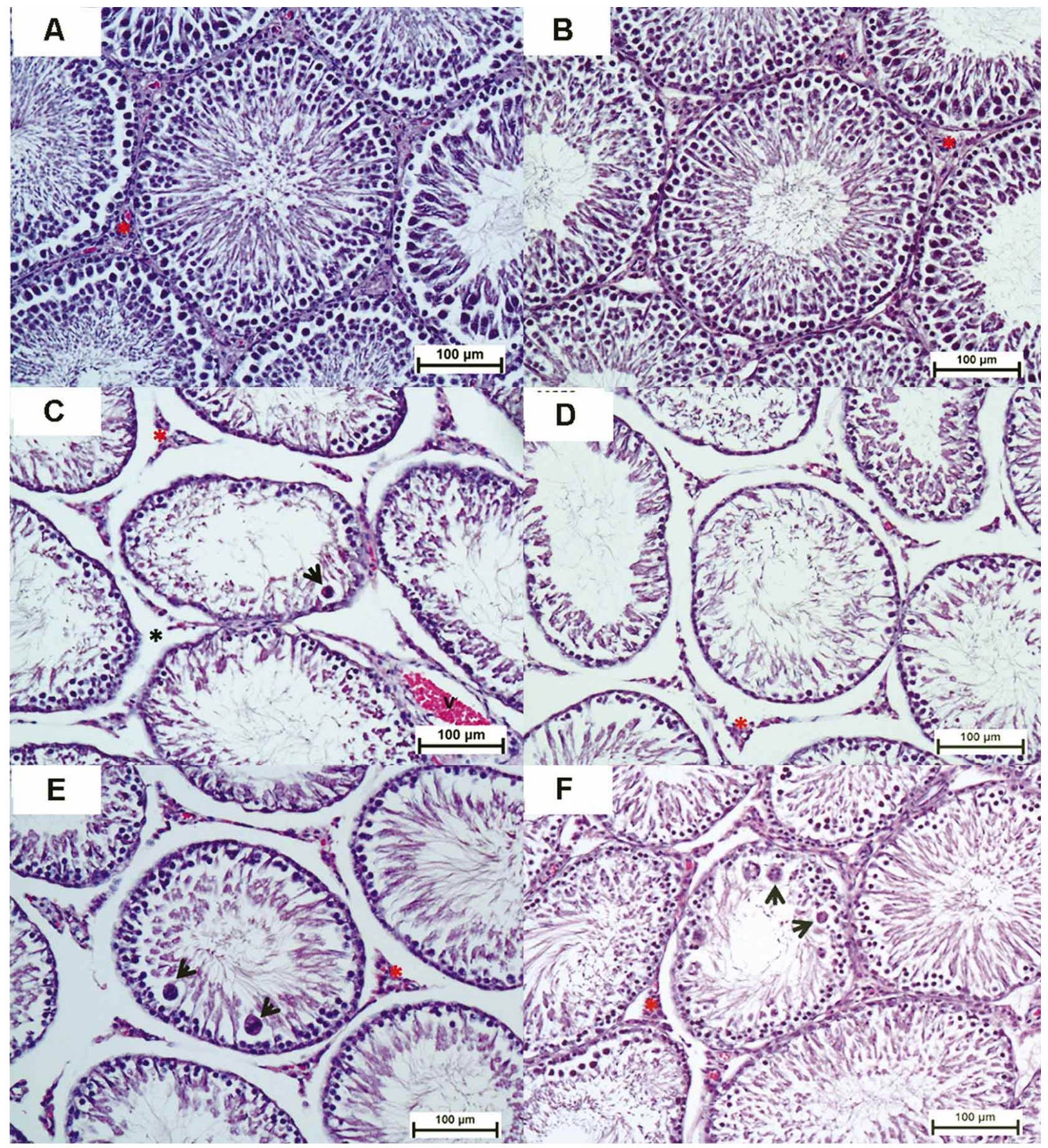

Fig. 1. Showing testicular histology (H\&E) of rats from a representative sections (A) Control; (B) MC200; (C) VPA; (D) MC50+VPA treated; (E) MC100+VPA treated; (F) MC200+VPA treated groups, respectively. Short arrows indicate multinucleated giant cells and asterisks indicate interstitial tissue space. 


\section{DISCUSSION}

In consistency to other reports (Sakr et al., 2014; Hamza \& Amin, 2007), our results also demonstrated that VPA treatments affect the weighs of body, testis, epididymis plus vas deferens and seminal vesicle, respectively (Table II). These adverse effects of VPA treatment include reductions of sperm concentration and seminiferous tubule diameters (Khan et al., 2011; Bairy et al.; Krogenase et al., 2008; Svenberg Roste et al., 2002; Nishimura et al. 2000). Recently, this study revealed that MC aril extract significantly prevented the adverse reproductive parameters including testicular damage in male rats induced with VPA (Table II and Fig. 1). However, MC extract did not significantly prevent the animal body and testicular weights but it tended to protect such parameters (Table I). It is possible that significant preventive effects might be promising if the higher dose of MC extract was performed. The increase of epididymis weight in MC-VPA treated groups was associated with that of epididymal sperm concentration (Table II). Obviously, MC extract prevented the damages of testicular tissue and seminiferous tubule diameters although some slight multinucleated giant cells were found in all MC-VPA treated groups (Fig. 1). Taken all results together, this study showed for the first time that $\mathrm{MC}$ extract has indeed protective effects on testicular damage induced by VPA. Many medicinal plants have been documented to have protective effects for adverse reproductive parameters and testicular damages in VPA animal experimental models (Sakr et al., 2014; Hamza \& Amin). Since MC extract has been proved for its high antioxidant activities (Kubola \& Siriamornpun, 2011), we assumed that MC study might have abilities in decreasing of malondialdehyde and increasing of catalase and glutathione peroxidase in the testicular tissue as previously reported (Sakr et al.; Hamza \& Amin). In further studies, the biochemical and molecular analyses will be performed to explain additional mechanisms of how the MC could prevent such adverse effects. The protective tissue damage effect demonstrated in this study is a phytotherapeutic property of MC extract besides other pharmacological properties shown in previous reports (Zheng et al.; Jung et al., 2013a, 2013b; Liu et al.; Chuethong et al.; Tien et al.; Kang et al.; Tsoi et al.; Xiao et al., 2007, 2009; Rajput et al., 2007, 2010). Moreover, MC extract indeed did not affect any male reproductive parameters including testicular histology as compared to the control. In conclusion, this study indicates that $\mathrm{MC}$ aril extract is safe for use and can protect adverse male reproductive parameters in treatment with VPA.

\section{ACKNOWLEDGMENTS}

This project was financially support by two grants from the Center for Research and Development of Herbal Health Product, Faculty of Pharmaceutical Sciences (No. RD-HHP 05) and the Invitation research grants from Faculty of Medicine, Khon Kaen University (No.I-57234) to Dr. Sitthichai Iamsaard.

SUKHORUM, W.; SAMPANNANG, A. \& SRIPANIDKULCHAI, B. \& IAMSAARD, S. El extracto del arilo Momordica cochinchinensis (L.) Spreng. previene los parámetros reproductivos adversos inducidos con ácido valproico en ratas macho. Int. J. Morphol., 34(3):870-876, 2016.

RESUMEN: El objetivo fue investigar el efecto protector del extracto de arilo de Momordica cochinchinensis (MC) sobre los parámetros reproductivos adversos de la rata macho inducida con ácido valproico (AV) que se utiliza comúnmente en el tratamiento de enfermedades epilépticas. Las ratas se dividieron en 6 grupos (control, AV, $200 \mathrm{mg} / \mathrm{kg}$ por peso corporal de PE solamente, y 50, 100, 200 $\mathrm{mg} / \mathrm{kg}$ por peso corporal $\mathrm{MC}+\mathrm{AV}$, respectivamente). Los animales fueron tratados previamente con extracto acuoso MC durante 23 días, antes de la administración de AV durante 10 días. Al término del experimento, se examinaron todos los parámetros reproductivos masculinos y la histología testicular. Los resultados indicaron que todas las dosis de PE protegen de manera significativa la disminución de los pesos de epidídimo y vesículas seminales, pero no de peso corporal y testicular. El extracto de MC también aumentó la concentración de espermatozoides y los diámetros de los túbulos seminíferos en los grupos de administración con MC+AV. Por otra parte, la histología testicular de los grupos MC+AV mostró una disminución significativa de histopatologías testiculares en comparación con el grupo AV. En conclusión, el extracto de arilo M. cochinchinensis puede prevenir la aparición de parámetros reproductivos masculinos negativos y los daños testiculares inducidos con AV. Ratas.

PALABRAS CLAVE: Momordica cochinchinensis; Ácido valproico; Parámetros reproductivos masculinos; Daño testicular; 


\section{REFERENCES}

Bairy, L.; Paul, V. \& Rao, Y. Reproductive toxicity of sodium valproate in male rats. Indian J. Pharmacol., 42(2):90-4, 2010.

Bauer, J.; Blumenthal, S.; Reuber, M. \& Stoffel-Wagner, B. Epilepsy syndrome, focus location, and treatment choice affect testicular function in men with epilepsy. Neurology., 62(2):243-6, 2004.

Chuethong, J.; Oda, K.; Sakurai, H.; Saiki, I. \& Leelamanit, W. Cochinin B, a novel ribosome-inactivating protein from the seeds of Momordica cochinchinensis. Biol. Pharm. Bull., 30(3):428-32, 2007.

Gelder, M.; Harrison, P. \& Cowen, P. Shorter Oxford Textbook of Psychiatry. $5^{\text {th }}$ ed. Oxford, Oxford University Press, 2006.

Hamza, A. A. \& Amin, A. Apium graveolens modulates sodium valproate-induced reproductive toxicity in rats. J. Exp. Zool. A Ecol. Genet. Physiol., 307(4):199-206, 2007.

Herzog, A. G. Disorders of reproduction in patients with epilepsy: primary neurological mechanisms. Seizure, 17(2):101-10, 2008.

Iamsaard, S.; Burawat, J.; Kanla, P.; Arun, S.; Sukhorum, W.; Sripanidkulchai, B.; Uabundit, N.; Wattathorn, J.; Hipkaeo, W.; Fongmoon, D. \& Kondo, H. Antioxidant activity and protective effect of Clitoria ternatea flower extract on testicular damage induced by ketoconazole in rats. J. Zhejiang Univ. Sci. B, 15(6):548-55, 2014.

Isojärvi, J. I.; Löfgren, E.; Juntunen, K. S.; Pakarinen, A. J.; Päivänsalo, M.; Rautakorpi, I. \& Tuomivaara, L. Effect of epilepsy and antiepileptic drugs on male reproductive health. Neurology, 62(2):247-53, 2004.

Jentink, J.; Loane, M. A.; Dolk, H.; Barisic, I.; Garne, E.; Morris, J. K.; de Jong-van den Berg, L. T. \& EUROCAT Antiepileptic Study Working Group. Valproic acid monotherapy in pregnancy and major congenital malformations. N. Engl. J. Med., 362(23):2185-93, 2010.

Jung, K.; Chin, Y. W.; Chung, Y. H.; Park, Y. H.; Yoo, H.; Min, D. S.; Lee, B. \& Kim, J. Anti-gastritis and wound healing effects of Momordicae Semen extract and its active component. Immunopharmacol. Immunotoxicol., 35(1):126-32, 2013a.

Jung, K.; Chin, Y. W.; Yoon, K. D.; Chae, H. S.; Kim, C. Y.; Yoo, H. \& Kim, J. Anti-inflammatory properties of a triterpenoidal glycoside from Momordica cochinchinensis in LPS-stimulated macrophages. Immunopharmacol. Immunotoxicol., 35(1):8-14, 2013b.

Kang, J. M.; Kim, N.; Kim, B.; Kim, J. H.; Lee, B. Y.; Park, J. H.; Lee, M. K.; Lee, H. S.; Kim, J. S.; Jung, H. C. \& Song, I. S. Enhancement of gastric ulcer healing and angiogenesis by cochinchina Momordica seed extract in rats. J. Korean Med. Sci., 25(6):875-81, 2010.

Khan, S.; Ahmad, T.; Parekh, C. V.; Trivedi, P. P.; Kushwaha, S. \& Jena, G. Investigation on sodium valproate induced germ cell damage, oxidative stress and genotoxicity in male Swiss mice. Reprod. Toxicol., 32(4):385-94, 2011.

Krogenase, A. K.; Taubøll, E.; Stien, A.; Oskam, I. C.; Lyche, J. L.; Dahl, E.; Thomassen, R. F.; Sweeney, T. \& Ropstad, E. Valproate affects reproductive endocrine function, testis diameter and some semen variables in non-epileptic adolescent goat bucks. Theriogenology, 70(1):15-26, 2008.

Kubola, J. \& Siriamornpun, S. Phytochemicals and antioxidant activity of different fruit fractions (peel, pulp, aril and seed) of Thai gac (Momordica cochinchinensis Spreng). Food Chem., 127(3):1138-45, 2011.

Liu, H. R.; Meng, L. Y.; Lin, Z.Y.; Shen, Y.; Yu, Y. Q. \& Zhu, Y. Z. Cochinchina momordica seed extract induces apoptosis and cell cycle arrest in human gastric cancer cells via PARP and p53 signal pathways. Nutr. Cancer, 64(7):1070-7, 2012.

Löscher, W. Basic pharmacology of valproate: a review after 35 years of clinical use for the treatment of epilepsy. C. N. S. Drugs, 16(10):669-94, 2002.

Nishimura, T.; Sakai, M. \& Yonezawa, H. Effects of valproic acid on fertility and reproductive organs in male rats. J. Toxicol. Sci., 25(2):85-93, 2000.

Rajput, Z. I.; Xiao, C. W.; Hu, S. H.; Arijo, A. G. \& Soomro, N. M. Improvement of the efficacy of influenza vaccination (H5N1) in chicken by using extract of Cochinchina momordica seed (ECMS). J. Zhejiang Univ. Sci. B, 8(5):331-7, 2007.

Rajput, Z. I.; Xiao, C. W.; Hu, S. H.; Habib, M. \& Soomro, N. A. Enhancement of immune responses to infectious bursal disease vaccine by supplement of an extract made from Momordica cochinchinensis (Lour.) Spreng. seeds. Poult. Sci., 89(6):112935,2010 .

Roste, L. S.; Tauboll, E.; Haugen, T. B.; Bjornenak, T.; Saetre, E. R. \& Gjerstad, L. Alterations in semen parameters in men with epilepsy treated with valproate or carbamazepine monotherapy. Eur. J. Neurol., 10(5):501-6, 2003.

Sakr, S. A.; Zowail, M. E. \& Marzouk, A. M. Effect of saffron (Crocus sativus L.) on sodium valporate induced cytogenetic and testicular alterations in albino rats. Anat. Cell Biol., 47(3):171-9, 2014.

Sveberg Roste, L.; Tauboll, E.; Isojärvi, J. I.; Pakarinen, A. J.; Huhtaniemi, I. T.; Knip, M. \& Gjerstad, L. Effects of chronic 
SUKHORUM, W.; SAMPANNANG, A. \& SRIPANIDKULCHAI, B. \& IAMSAARD, S. Momordica cochinchinensis (L.) Spreng aril extract prevents adverse reproductive parameters of male rats induced with valproic acid. Int. J. Morphol., 34(3):870-876, 2016.

valproate treatment on reproductive endocrine hormones in female and male Wistar rats. Reprod. Toxicol., 16(6):767-73, 2002.

Tien, P. G.; Kayama, F.; Konishi, F.; Tamemoto, H.; Kasono, K.; Hung, N. T.; Kuroki, M.; Ishikawa, S. E.; Van, C. N. \& Kawakami, M. Inhibition of tumor growth and angiogenesis by water extract of Gac fruit (Momordica cochinchinensis Spreng). Int. J. Oncol., 26(4):881-9, 2005.

Tsoi, A. Y.; Ng, T. B. \& Fong, W. P. Immunomodulatory activity of a chymotrypsin inhibitor from Momordica cochinchinensis seeds. J. Pept. Sci., 12(9):605-11, 2006.

Watkins, R. J.; Gough, A. W.; McGuire, E. J.; Goldenthal, E. \& de la Iglesia, F. A. Calcium valproate-induced uterine adenocarcinomas in Wistar rats. Toxicology, 71(1-2):35-47, 1992.

Witczak, M.; Kociszewska, I.; Wilczyn’ski, J.; Lopaczyn’ska, D. \& Ferenc, T. Evaluation of chromosome aberrations, sister chromatid exchange and micronuclei in cultured cord-blood lymphocytes of newborns of women treated for epilepsy during pregnancy. Mutat. Res., 701(2):111-7, 2010.

Xiao, C.; Rajput, Z. I.; Liu, D. \& Hu, S. Enhancement of serological immune responses to foot-and-mouth disease vaccine by a supplement made of extract of cochinchina momordica seeds. Clin. Vaccine Immunol., 14(12):1634-9, 2007.

Xiao, C.; Bao, G. \& Hu, S. Enhancement of immune responses to Newcastle disease vaccine by a supplement of extract of Momordica cochinchinensis (Lour.) Spreng. seeds. Poult. Sci., 88(11):2293-7, 2009.

Zheng, L.; Zhang, Y. M.; Zhan, Y. Z. \& Liu, C. X. Momordica cochinchinensis seed extracts suppress migration and invasion of human breast cancer ZR-75-30 cells via down-regulating MMP-2 and MMP-9. Asian Pac. J. Cancer Prev., 15(3):1105$10,2014$.

\author{
Correspondence to: \\ Dr. Sitthichai lamsaard \\ Department of Anatomy \\ Faculty of Medicine \\ Khon Kaen University \\ 123 Mitraparp Road, Amphoe Muang \\ Khon Kaen 40002 \\ THAILAND
}

Tel: +66-4336-3212

Fax: +66-4336-3212

Email: sittia@kku.ac.th

Received: 04-05-2015

Accepted: 14-04-2016 